\title{
STUDI DESKRIPSI HUBUNGAN ANTARA NATURALNESS INDEX \\ DAN BIODIVERSITY INDEXDENGAN IKLIM MIKRO \\ PADA KELURAHANJATIMULYO, MOJOLANGU, DAN \\ MERGOSONODI KOTA MALANG BERBASIS \\ ECOLOGICALLANDSCAPE
}

\section{Prastiyo1, Mahrus Ismail $^{2}$, Abdul Basith ${ }^{3}$, dan Munawir Sazali ${ }^{4}$ 1,2,3Pascasarjana Jurusan Biologi, FMIPA Universitas Brawijaya \\ ${ }^{4}$ Dosen FITK IAIN Mataram}

\begin{abstract}
Abstrak
Laju pertumbuhan penduduk Kota Malang sejak tahun 2001 semakin meningkat seiring dengan perkembangan perekonomian, pemukiman, pendidikan, dan budaya. Peningkatan laju pembangunan mengakibatkan peningkatan alih fungsi lahan, khususnya area RTH. Selain itu, peranan ecological services terus mengalami gradasi sehingga menyebabkan penurunan kenyamanan warga. Penelitian komparasional ini dilakukan pada tiga kelurahan, yaitu Kelurahan Jatimulyo, Kelurahan Mojolangu, dan Kelurahan Mergosono. Penentuan titik lokasi penelitian dan titik koordinat dengan memanfaatkan program Google Maps. Berdasarkan pada penghitungan naturalness index dan indeks kualitas biodiversitas kelurahan dengan nilai kealamian (naturalness) dan kualitas biodiversitas tertinggi adalah Kelurahan Jatimulyo, sedangkan yang terendah adalah Kelurahan Mergosono. Kontribusi naturalness index dan indeks kualitas biodiversitas terhadap suhu adalah 67\% dan 82,86\% dengan persamaan regresi $y=33,621-3,6686 x$ dan $y=31,138-0,0054 x$. Kontribusi naturalness index dan indeks kualitas biodiversitas terhadap kelembaban adalah 42,26\% dan 60,66\% dengan persamaan regresi $y=55,412+7,3164 x$ dan $y=60,195+0,0166 x$. Perbedaan kontribusi dan persamaan regresi naturalness index dan indeks kualitas biodiversitas disebabkan karena karakteristik masing-masing indeks. Pada indeks kualitas biodiversitas hanya 4 dari total 29 karakter yang tersedia.
\end{abstract}

Kata Kunci: Naturalness index, indeks kualitas biodiversitas, iklim mikro, ecological landscape, Kota Malang 


\section{PENDAHULUAN}

Jumlah penduduk Kota Malang pada tahun 2010 tercatat 820.243 jiwa. Jika diban-dingkan dengan hasil sensus penduduk tahun 2000 laju pertumbuhan penduduk tahun 2010 sebesar 0,80 persen. Jika ditinjau dari luas total wilayah Kota Malang $(110,06$ $\mathrm{km}^{2}$ ), maka kepadatan penduduk Kota Malang adalah sebesar 7.453 jiwa $/ \mathrm{km}^{2}$ (BPS Kota Malang, 2011). Pertumbuhan penduduk perkotaan yang semakin pesat tersebut beriringan dengan perkembangan perekonomian, pemukiman, pen-didikan, dan budaya. Peningkatan jumlah pen-duduk perkotaan menimbulkan tekanan, cukup besar terhadap sumberdaya dan lingkungan perkotaan. Salah satu dampak adalah terjadi-nya konversi lahan. Lahan yang semula ber-fungsi sebagai ruang tumbuh berbagai vegetasi berubah menjadi ruang pemukiman dan sarana pendukung kegiatan di perkotaan (Setyowati, 2008).

Salah satu dampak dari konversi lahan adalah perubahan suhu udara. Perubahan suhu udara di KotaMalang diakibatkan oleh Ruang Terbuka Hijau (RTH) yang banyak mengalami alih fungsi menjadi bangunan-bangunan seperti ruko-ruko, perumahan, dan pusat perbelanjaan.Temuan dan data hasil kajian Badan Perencanaan Pembangunan Daerah (Bappeda) Kota Malang menyebutkan bahwa RTH di Kota Malang kini hanya sebesar $17 \%$ dari total luas wilayah yang mencapai $110 \mathrm{~km}^{2}$ tersebut. Hal ini tentu merupakan suatu pelanggaran terhadap UU Nomor 26 Tahun 2007.Pada UU Nomor 26 Tahun 2007 dijelaskan bahwa luasan RTH di wilayah per-kotaanminimal 30\% dari total luas wilayah, dengan rincian 20\% merupakan RTH untuk alokasi publik dan $10 \%$ untuk alokasi RTH privat.

Perhatian Pemerintah Kota Malang dan beberapa elemen masyarakat sebenarnya pernah nampak pada pencanangan program Malang Ijo Royo-royo yang disponsori oleh salah satu perusahaan rokok nasional. Namun, evaluasi berkelanjutan atas program tersebut nampaknya belum cukup optimal. Disisi lain, alih fungsi lahan justru terjadi pada daerah-daerah resapan Kota Malang. 
Penelitian ini dilakukan untuk meng-identifikasi dan membandingkan naturalness index dan indeks kualitas biodiversitas sebagai prediktor terhadap faktor suhu dan kelembaban pada Kelurahan Jatimulyo, Mojolangu, dan Mergosono di Kota Malang. Konsep naturalness (kealamian) dideskripsi-kan sebagai suatu nilai konservasi dan des-kriptor pada suatu wilayah. Ranking natural-ness index dikategorikan pada rentang nilai maksimum 10 untuk sistem alami absolut hingga nilai minimum (0) untuk sistem buatan absolut (Machado, 2004). Indeks kualitas biodiversitas merupakan suatu pendekatan untuk mendeskripsikan beragam dampak dari penggunaan lahan terhadap biodiversitas (Pagiola, et al. 2004). Data yang terkumpul pada akhirnya akan dikaitkan pula dengan tingkat kenyamanan warga.

Hasil penelitian ini dapat dimanfaat-kan sebagai salah satu sumber informasi untuk pertimbangan pembangunan berkelanjutan di Kota Malang.

\section{METODE PENELITIAN}

Penelitian lapangan dilakukan pada 5 Novemberhingga 24 Desember 2012 pada tiga kelurahan di Kota Malang, meliputi Kelurahan Jatimulyo, Mojolangu, dan Mergosono. Pada masingmasing kelurahan ditentukan tiga titik sampel dengan menggunakan fasilitas google map; sedangkan pencarian lokasi yang sesuai titik koordinat menggunakan alat GPS. Pada Kelurahan Jatimulyo, koordinat titik sampelnya meliputi: (1) 7056'6" LS dan 112037'42" BT; (2) 7055'58" LS dan 112036'35" BT;(3) 7055'48" LS dan $112^{0} 36^{\prime} 34^{\prime \prime}$ BT. Koordinat titik sampel pada Kelurahan Mojolangu adalah: (1) 7055'58" LS dan 112036'35" BT; (2) 7056'13" LS dan 112037'42" BT; dan (3) 7056'38" LS dan 112037'6" BT. Koordinat titik sampel pada Kelurahan Mergosono dirinci berikut: (1) 7059'39" LS dan 112038'5 BT; (2) 7059'52" LS dan 112037'59" BT; (3) 800'1" LS dan 112037'57 BT. Analisis landscape yang digunakan pada penelitian ini meliputi naturalness index berdasarkan pada penjelasan Machado (2004) dan Indeks Biodiversitas yang dikembangkan oleh Pagiola (2004) sebagai 
prediktor. Gambar 3 dan 4 menunjukkan landscape area penelitian yang telah dikonversi dalam bentuk peta kealamian (map of naturalness) dan peta kualitas biodiversitas. Rumus yang digunakan untuk menentukan nilai naturalness index (NI) dan indeks kualitas biodiversitas (IKB) disajikan berikut ini.

$$
\text { IKB atau NI }=\frac{\text { Luas Wilayah } x \text { Nilai Indeks }}{\text { Luas Total Wilayah }}
$$

\section{Keterangan:}

$\mathrm{IKB}=$ indeks kualitas biodiversitas

$\mathrm{NI} \quad=$ naturalness index

Iklim mikro yang diukur meliputi suhu $\left({ }^{0} \mathrm{C}\right)$ dan kelembaban (\%). Pengukuran iklim mikro (suhu dan kelembaban) dilakukan secara bersamaan di tiga kelurahan pada tiga titik koordinat yang telah ditentukan dalam lima kali pengamatan pada semua titik lokasi.Pengambilan data suhu dan kelembaban dilakukan secara konsisten antara pukul 15.00-16.00 WIB.

Uji statistik dilakukan dengan meng-gunakan uji korelasi dan regresi dua jalur dengan naturalness index dan indeks kualitas biodiversitassebagai prediktor atas iklim mikro (suhu dan kelembaban). Data sekunder berupa tingkat kenyamanan warga tiga kelurahan didapatkan dari hasil wawancara semi terbuka. Penentuan responden adalah dengan menggunakan teknik simplerandom sampling. Jumlah responden yang diwawan-carai adalah 10 orang pada masing-masing titik koordinat.

\section{HASIL DAN PEMBAHASAN}

\section{Iklim Mikro}

Iklim mikro yang dianalisis pada penelitian ini meliputi suhu dan kelembaban. Pada Gambar 1 nampak bahwa rata-rata 
suhu tertinggi terdapat pada Kelurahan Mergosono, yaitu 30,90 C; sedangkan rata-rata suhu terendah terdapat pada Kelurahan Mojolangu, yaitu 29,3 $3^{\circ}$ C. Selisih antara suhu tertinggi dan terendah adalah $1,6^{\circ} \mathrm{C}$. Rata-rata kelembaban tertinggi terdapat pada Kelurahan Mojolangu, yaitu 64,7\%; sedangkan rata-rata kelembaban terendah terdapat pada Kelurahan Mergosono, yaitu $60,7 \%$. Selisih antara kelembaban tertinggi dan kelembaban terendah adalah $4 \%$.

\section{Naturalness Index}

Berdasarkan penghitungan naturalness index didapatkan beberapa skor seperti yang tertera pada Gambar 2.A. Wilayah dengan skor 5 pada Kelurahan Jatimulyo lebih luas dibandingkan dengan Kelurahan Mojolangu dan Mergosono, wilayah dengan skor 4 pada Kelurahan Mojolangu lebih luas dibanding-kan Kelurahan Jatimulyo dan Mergosono, wilayah dengan skor 3 pada Kelurahan Jatimulyo lebih luas dibandingkan dengan Kelurahan Mojolangu dan Mergosono, wilayah dengan skor 2 pada Kelurahan Mergosono lebih luas dibandingkan dengan Kelurahan Mojolangu dan Jatimulyo, wilayah dengan skor 1 pada Kelurahan Mergosono jauh lebih luas dibandingkan dengan Kelurahan Mojolangu dan Jatimulyo, dan wilayah dengan skor 0 pada Kelurahan Mojolangu lebih luas dibandingkan dengan pada Kelurahan Mergosono dan Jatimulyo. Keseluruhan nilai naturalness index pada Kelurahan Jatimulyo, Mojolangu, dan Mergo-sono berturut-turut adalah 1,11; 1,04; dan 0,77. Berdasarkan pada hasil penghitungan tersebut dapat disimpulkan bahwa tingkat kealamian (naturalness) tertinggi adalah pada Kelurahan Jatimulyo dan tingkat kealamian terendah adalah pada Kelurahan Mergosono. Gambar 3, secara berturut-turut merupakan peta kealamian pada salah satu titik dari masing-masing kelurahan. 


\section{Indeks Kualitas Biodiversitas}

Berdasarkan penghitungan indeks kualitas biodiversitas didapatkan beberapa ragam subyek indeks seperti yang disajikan pada Gambar 2.B. Jumlah ragam tanaman berkayu (diversify timber plant) dan tanaman semak (schrub) pada Kelurahan Mojolangu lebih tinggi dibandingkan dengan Kelurahan Jatimulyo dan Kelurahan Mergosono. Ladang tanaman sejenis (monoculture fruit crop) dan ladang tanaman tahunan (annual crop) pada Kelurahan Jatimulyo lebih tinggi dibanding-kan pada Kelurahan Mojolangu, namun pada Kelurahan Mergosono tidak ada samasekali. Keseluruhan nilai indeks kualitas biodiversitas pada Kelurahan Jatimulyo, Mojolangu, dan Mergosono berturut-turut adalah 281,75; 278,75; dan 45. Berdasarkan pada hasil penghitungan tersebut dapat disimpulkan bahwa nilai kualitas biodiversitas tertinggi adalah pada Kelurahan Jatimulyo dan nilai kualitas biodiversitas terendah pada Kelurahan Mergosono. Gambar 4, secara berturut-turut merupakan peta batas biodiversitas pada salah satu titik dari masing-masing kelurahan.

\section{Kontribusi Naturalness Index dan Indeks Kualitas Biodiversitas terhadap Iklim Mikro}

Berdasarkan uji statistik korelasi dan regresi diketahui tingkat kontribusi dan persamaan regresi naturalness index dan indeks kualitas biodiversitas terhadap iklim mikro (suhu dan kelembaban). Kontribusi naturalness index terhadap suhu adalah $67 \%$ dengan persamaan regresi $\mathrm{y}=33,621-3,6686 \mathrm{x}$, sedangkan $33 \%$ merupakan kontribusi faktor-faktor lain diluar naturalness index. Kontribusi indeks kualitas biodiversitas terhadap suhu adalah $82,86 \%$ dengan persamaan regresi $\mathrm{y}=31,138-0,0054 \mathrm{x}$, sedangkan 17,14\% merupakan kontribusi faktor-faktor lain di luar indeks kualitas biodiversitas. Garis persamaan regresi naturalness index dan indeks kualitas biodiversitas terhadap suhu disajikan pada Gambar 5 (A) dan 5 (B).

Kontribusi naturalness index terhadap kelembaban adalah $42,26 \%$ dengan persamaan regresi $y=55,412+7,3164 x$, sedangkan $57,74 \%$ merupakan kontribusi faktor-faktor lain di luar 
PRASTIYO, DKK.

naturalness index. Kontibusi indeks kualitas biodiversitas terhadap kelembaban adalah 60,66\% dengan persamaan regresi $y=60,195+0,0166 x$, sedangkan 39,34\% merupakan kontribusi faktor-faktor lain di luar indeks kualitas biodiversitas. Garis persamaan regresi naturalness index dan indeks kualitas biodiversitas terhadap kelembaban disajikan pada Gambar 5 (C) dan 5 (D).

\section{Suhu dan Kelembaban}

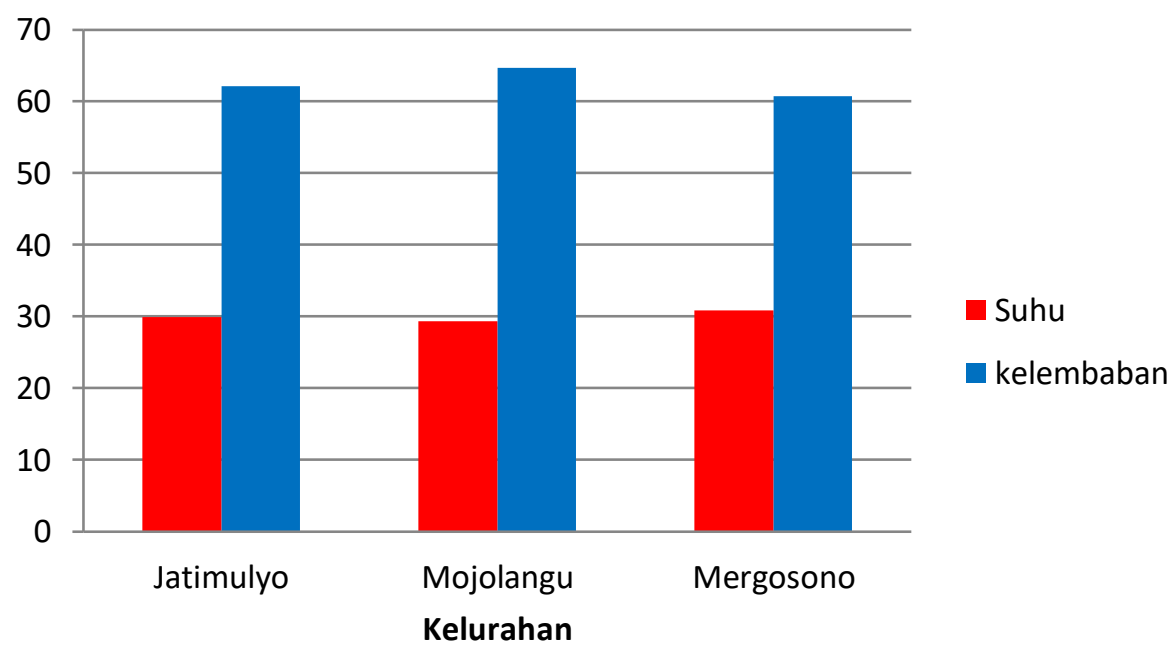

\section{Gambar 1}

Perbandingan suhu dan kelembaban Pada Kelurahan Jatimulyo, Mojolangu dan Mergosono 

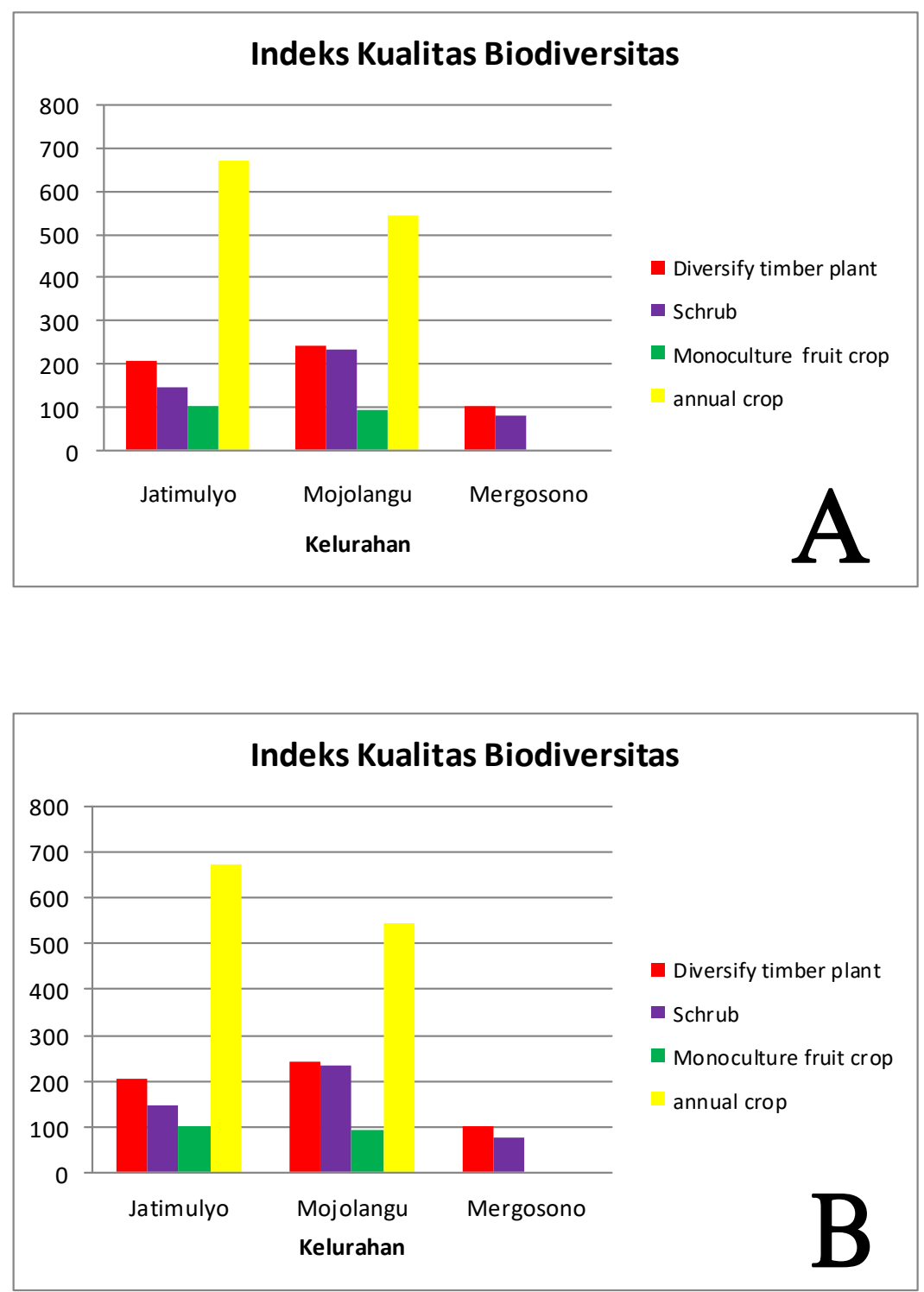

\section{Gambar 2}

Rincian Skor, (A) Naturalness Index dan Indeks dan (B) Kualitas Biodiversitaspada Kelurahan Jatimulyo, Mojolangu Dan Mergosono 
PRASTIYO, DKK.
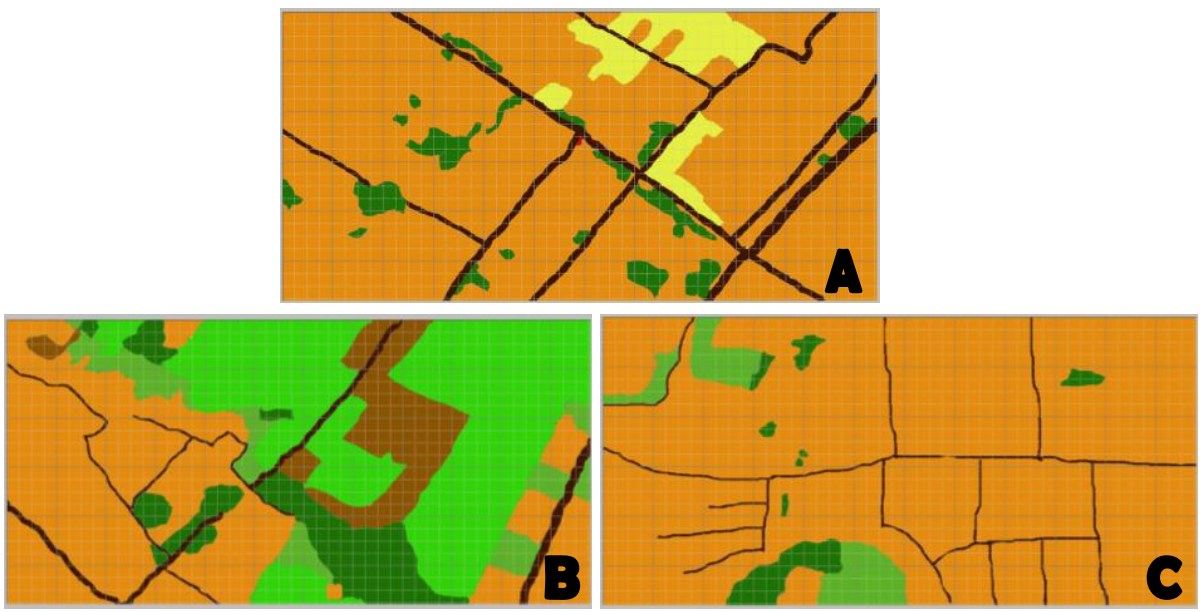

Gambar 3

Peta kealamian (map of naturalness) pada salah satu titik di setiap kelurahan: (A) Kelurahan Jatimulyo, (B) Kelurahan Mojolangu, (C) Kelurahan Mergosono

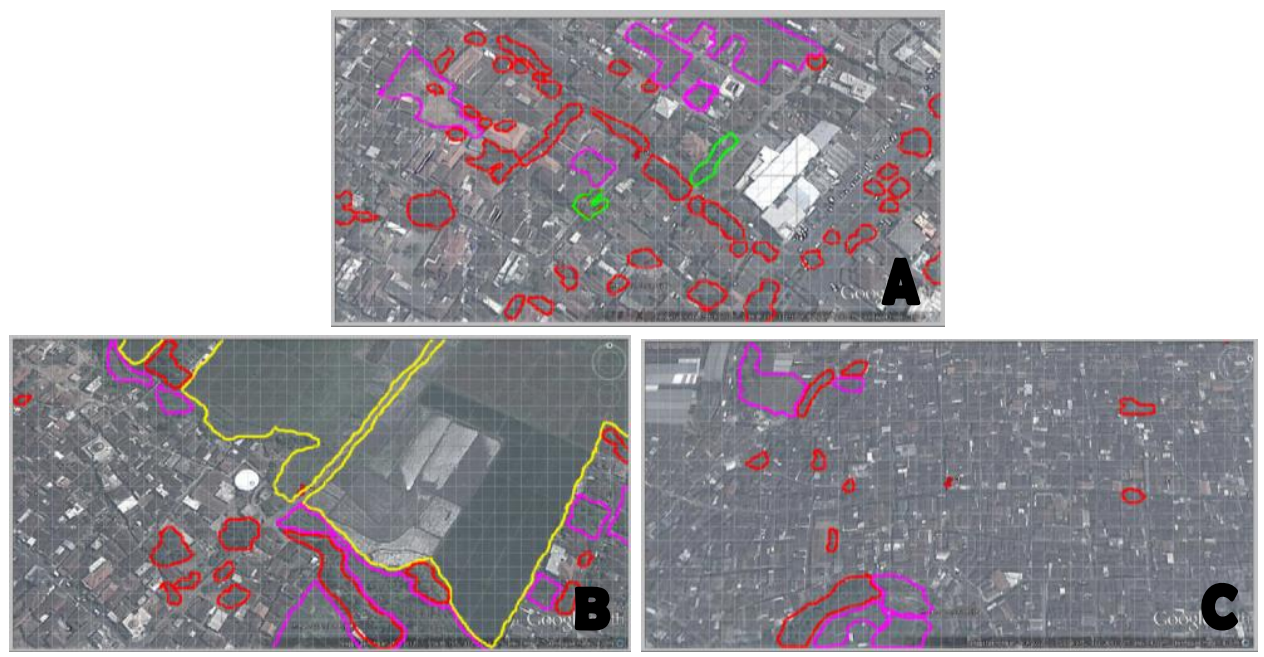

Gambar 4

Peta kualitas biodiversitas pada salah satu titik di setiap kelurahan:(A) Kelurahan Jatimulyo, (B) Kelurahan Mojolangu, (C) Kelurahan Mergosono

26 BIOTA: Jurnal Tadris IPA Biologi FITK IAIN Mataram 

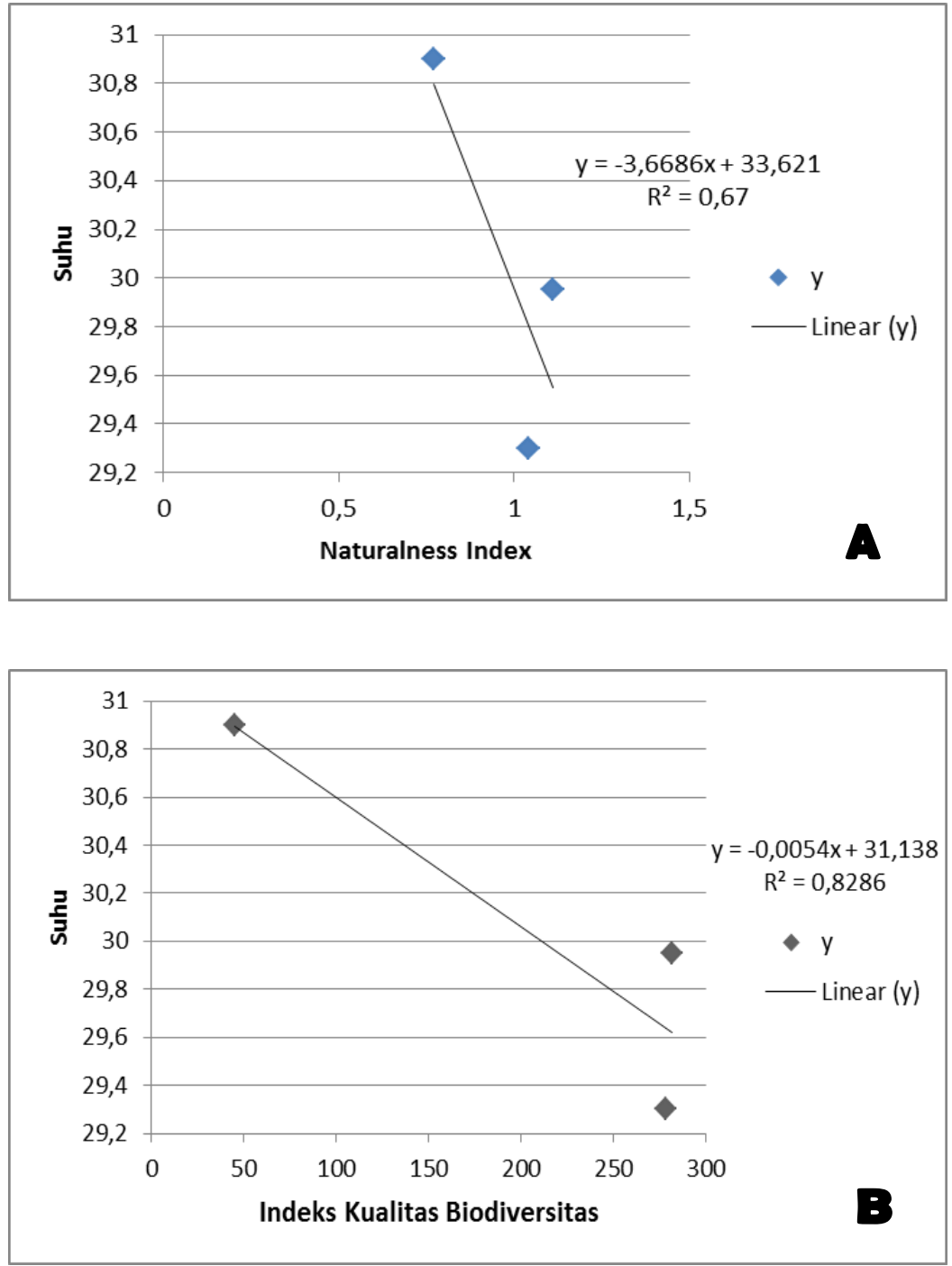

Gambar 5

Garis persamaan regresi naturalness index dan indeks kualitas biodiversitas terhadap suhu 
PRASTIYO, DKK.
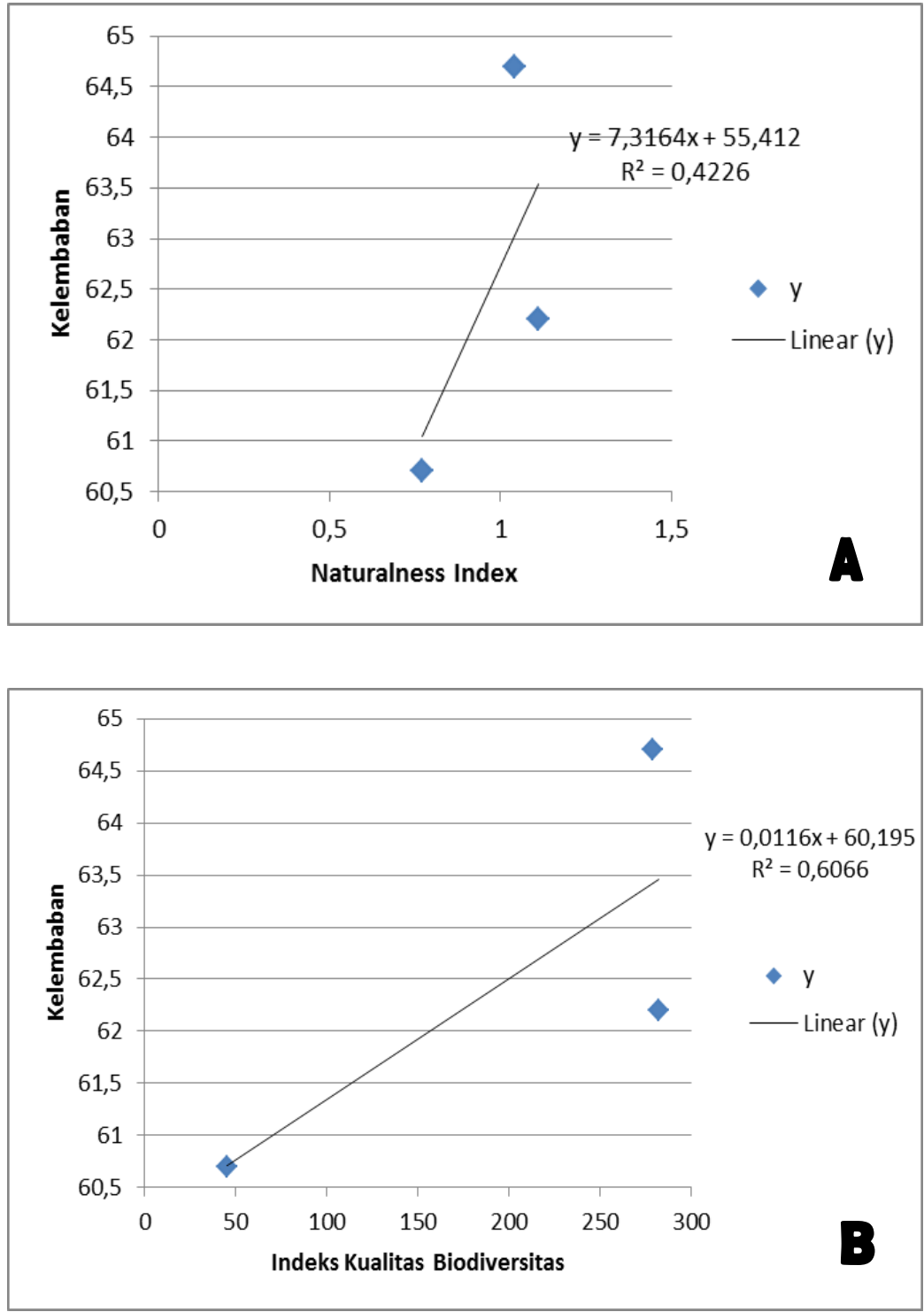

Gambar 6

Garis persamaan regresi naturalness index

dan indeks kualitas biodiversitas terhadap kelembaban 
Salah satu masalah lingkungan hidup di daerah perkotaan adalah semakin ber-kurangnya Ruang Terbuka Hijau (RTH). Menurut Setyowati (2008) hilangnya RTH merupakan salah satu pemicu munculnya heat island dan hilangnya pengendali emisi kota. Peningkatan suhu dan penurunan kelembaban yang terjadi pada sistem iklim bumi merupa-kan salah satu hal yang jelas terasa.

Rata-rata total suhu pada Kelurahan Mergosono lebih tinggi dibandingkan dengan Kelurahan Jatimulyo dan Mojolangu. Ratarata total suhu ini berbanding terbalik dengan rata-rata total kelembaban. Pada Kelurahan Mojolangu, rata-rata total kelembaban lebih tinggi dibandingkan Kelurahan Jatimulyo dan Kelurahan Mergosono.

Suhu tubuh manusia pada umumnya adalah $37^{0} \mathrm{C}$. Berdasarkan pada rata-rata suhu lingkungan yang didapatkan pada penelitian ini, maka selisih antara rata-rata suhu total lingkungan dengan suhu tubuh normal manusia adalah pada setiap kelurahan adalah $7,05^{\circ} \mathrm{C}, 7,7^{0} \mathrm{C}$, dan $6,1^{\circ} \mathrm{C}$. Menurut Tyubee (2004) pada umumnya rentang temperatur yang menjadikan manusia merasa nyaman adalah $26^{\circ} \mathrm{C}$ hingga $32^{\circ} \mathrm{C}$ atau pada kisaran selisih $11^{\circ} \mathrm{C}$ hingga $5^{\circ} \mathrm{C}$ dengan tubuh manusia. Hasil penelitian ini sejalan dengan hasil wawancara yang mengungkap bahwa seluruh hampir seluruh warga pada setiap kelurahan merasa nyaman.

Kelembaban yang nyaman bagi manusia adalah antara 50\%70\% (Sookchaiya, 2010). Dengan demikian kelembaban yang terdapat pada masing-masing kelurahan berada pada kisaran kenyamanan.

Berdasarkan pada penilaian dengan menggunakan naturalness index, didapatkan bahwa wilayah terluas yang mendapatkan skor 5 adalah Kelurahan Jatimulyo. Penentuan skor 5 didasarkan pada kondisi wilayah yang aktivitas manusia yang semakin berkembang, sedikit pengendalian pada proses biologis, dan pengendalian air yang cenderung pasif, misal-nya air untuk kebutuhan irigasi sawah (Machado, 2004). Penentuan skor 1 didasar-kan pada suatu kondisi dimana seluruh lahan didominasi 
oleh buatan manusia (artificial) dan ketergantungan yang tinggi pada masukan energi dan benda (misalnya makanan) dari luar wilayah. Kelurahan Mergosono mempunyai wilayah dengan skor 1 yang lebih tinggi dibandingkan dengan kelurahan yang lain.

Perbedaan kecenderungan yang muncul pada hasil uji korelasi dan persamaan regresi menunjukkan bahwa naturalness index dan indeks kualitas biodiversitas. Pagiola, et al. (2004) mengemukakan bahwa pada indeks kualitas biodiversitas terdapat keterbatasan, yaitu sangat bergantung pada karakteristik lahan yang digunakan atau yang dialihfungsi-kan, lokasi wilayah, dan hubungan antar lahan. Dibandingkan dengan indeks kualitas biodiversitas, naturalness index lebih me-mungkinkan diaplikasikan pada beragam lingkungan. Hal ini disebabkan karena indeks yang dikembangkan oleh Machado (2004) ini mengembangkan naturalnessindex dalam bentuk rangking (atau tingkatan) dengan skor maksimum (10) untuk suatu kondisi lingkungan yang sangat alamiah dan skor mini-mum (0) untuk suatu kondisi sistem yang absolut buatan manusia.

\section{PENUTUP}

Berdasarkan pada penelitian dapat dimunculkan beberapa kesimpulan, yaitu konservasi RTH perlu dipertimbangkan dalam laju pembangunan dan penggunaan indeks untuk menilai kondisi landskape perkotaan dapat menggunakan naturalness index dan indeks kualitas biodiversitas yang terintegrasi.

\section{DAFTAR PUSTAKA}

Badan Pusat Statistik Kota Malang. 2011.

Machado, A. 2004. An Index of Naturalness. Journal of Nature Conservation, 12 , 95-110.

Setyowati, D. L. 2008. Iklim Mikro dan Kebutuhan Ruang Terbuka Hijau di Kota Semarang. Jurnal Manusia dan Lingkungan, 15 (3): 125-140. 
Pagiola, S., Agostini, P., Gobbi, J., Haan, D. Ibrahim, M., Murgueitio, E., Ramirez, E., Rosales, M. \& Ruiz, J.P. 2004. Paying for Biodiversity Concervation Services in Agricultural Landscapes. Environment Department Papers, No. 96.

Tyubee, B. T. 2004. Thermal Problem and Physiological Indoor Comfort in Makurdi, Nigeria. International Journal of Science and Technological Research, 1 (1): 152-159. 